\title{
Encuesta sobre el cuidado de los seres queridos en Puerto Rico
}

Encuesta sobre el cuidado de los seres queridos en Puerto Rico El 84\% de los adultos de 45 años o más en Puerto Rico quieren recibir cuidados en el hogar*

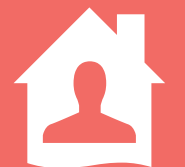

94\% piensan que es importante

tener servicios disponibles para ayudar a las

personas a permanecer en sus hogares

$94 \%$ dicen que se necesitan más recursos
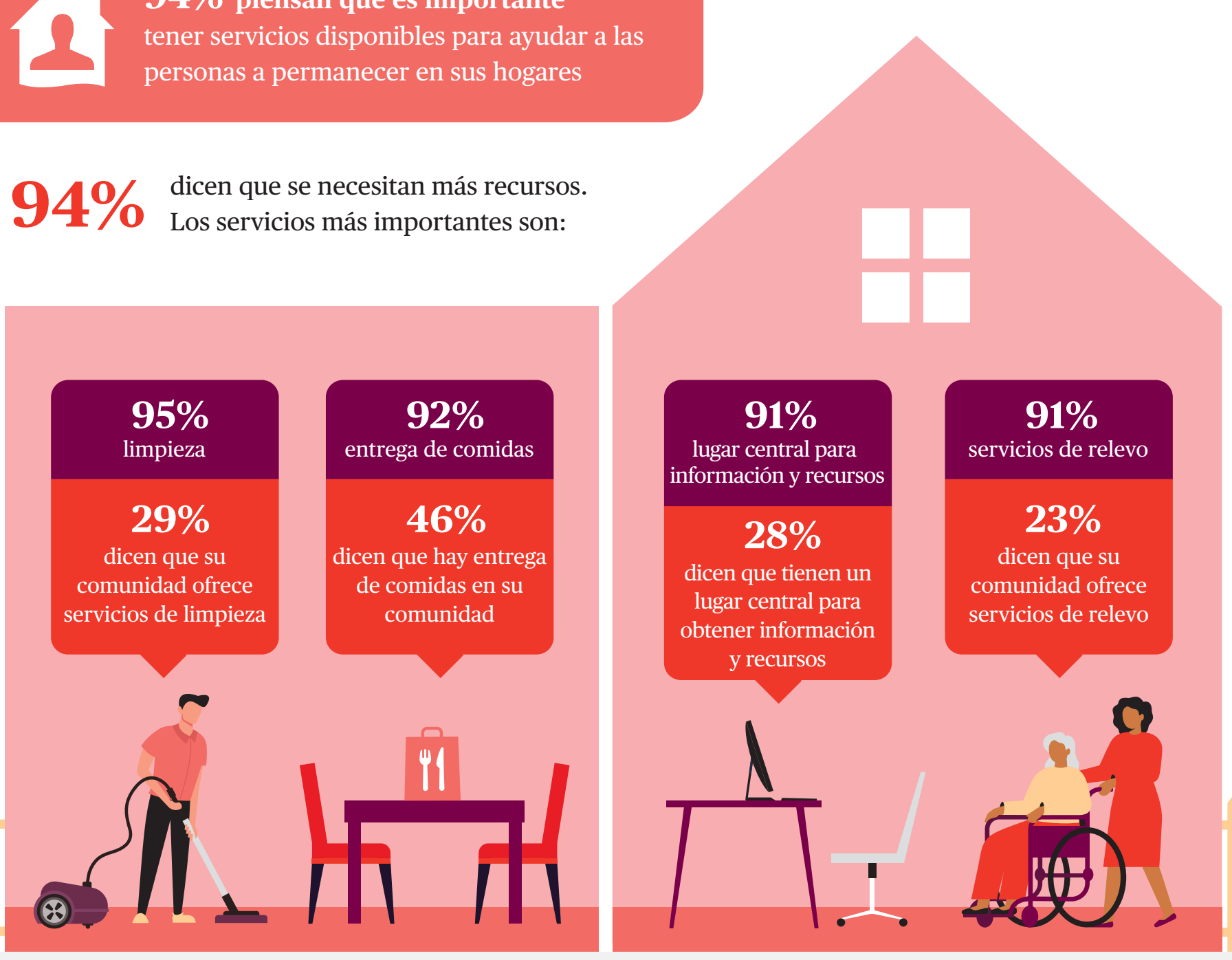

*La muestra incluye a los votantes registrados de Puerto Rico de 45 años o más 